【報 告】

UDC : 624.074:620.1
日本建築学会構造系論文報告集 第 422 号・1991 年 4.月 Journal of Struct. Constr. Engng, AIJ, No. 422, Apr., 1991

\title{
太径ボルトを用いたシステムトラスの疲労実験 EXPERIMENTAL STUDY ON FATIGUE PROPERTIES OF LARGE DIAMETER BOLTS FOR SYSTEM TRUSS
}

\author{
岩田 衛*, 和田 章**, 白井貴志***
}

Mamoru IWATA, Akira WADA and Takashi SHIRAI

\begin{abstract}
When discussing system truss fatigue, fatigue failure of bolts poses the most serious problem. This paper tries to clarify the fatigue properties which is peculiar to bolt joints of system trusses. It explains fatigue tests conducted on actual connection models and analyzes fatigue properties in volved.
\end{abstract}

Keywords : fatigue, large diameter bolt, system truss, connection, bolt joint 疲労, 太径ボルト, システムトラス, 接合部, ボルト接合

1. 序

システムトラスとは，立体トラスの弦材，斜材となる 鋼管部材と，接合部本体としての球体ノードを，建設現 場でボルト接合することにより，鋼管立体トラスを組み 立てる構法である(図一1)文!。このようなシステムト ラスは，作用外力が部材の中間には作用せず，ノードの みに働くとき，鋼管部材には，引張力または圧縮力の軸 力のみが生じ, 力学的に極めて効率の良い構造である。 システムトラスの構造全体の耐力は，以下に述べるよう に，個々の鋼管部材の耐力と，接合部の耐力が構造全体 へ及ぼす影響に対応して決まる。鋼管部材が過大な引張 軸力を受けると，部材は引張降伏するが，部材耐力は低 下しないため, 不静定次数が高ければ，構造全体の耐力 は更に上昇する。鋼管部材が過大な圧縮力を受けると, 部材は座屈する。その挙動は座屈長さによって異なり, 座屈した部材の耐力は低下するが，圧縮変形量に応じた 残留耐力を持つため，力の再配分が行われ，部材の座屈

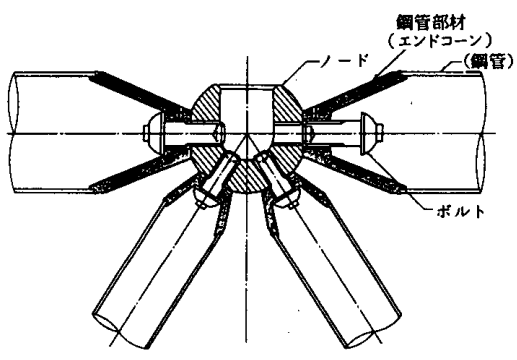

図一1 システムトラス接合部
現象がそのまま構造全体の耐力低下になる場合は少な い汶。しかし，鋼管部材とノードを結び付けているボ ルトが破断すると,接合部の耐力は突然ゼロになるので, 構造全体の耐力低下に及ぼす影響は極めて大きい。この ような観点から，著者らは，先にシステムトラスが大き な過荷重を受け，鋼管部材に過大な軸力が生じている状 態で，一つのノードに集まる部材間で，たとえ過大な相 対回転角が生じても，ボルトの破断が起こらない条件を 把握する研究を行った文)。

ところで, 最近, システムトラスの適用笧囲が高まり， クレーン等の繰返し荷重や，風による振動を受けるシス テムトラスが設計されるようになってきた。この場合， システムトラスの設計に当たっては，静的な耐力に関す る挙動のみでなく，疲労特性に関する挙動にも考慮をは らう必要がある。システムトラスの疲労を論じるとき, ボルトの疲労破壊が最も問題となる。なぜならば，図一 1 に示すようなシステムトラスの接合方法は，高力ボル 卜を用いているにもかかわらず，材間圧縮力の減少に よって引張力を伝える，いわゆる高力ボルト引張接合と はならず，作用変動荷重は，直接ボルトの変動軸力にな るからである。引張接合にできない理由として，通常規 模のシステムトラスにおいては，M 30 以上の太径ボル トが使われるため，これらのボルトに見合う大きな初期 軸力をボルトに導入することが極めて難しいこと，また， たとえ大きな初期軸力を導入する手法が開発されたとし ても，万一，製作誤差等によって，鋼管部材とノードの
* 新日本製鐵株式會社 $\cdot$ 工博

** 東京工業大学 教授・工博

*** 新日本製鐵株式會社・工修
Nippon Steel Corporation, Dr. Eng.

Prof., Tokyo Institute of Technology, Dr. Eng.

Nippon Steel Corporation, M. Eng. 
間に肌隙が生じている場合に，これらを強引に引き寄せ ると，材間圧縮力を生じさせることができず，周辺の鋼 管部材自身に初期応力を生じさせてしまうことの二点が 挙げられる。

一般に繰返し荷重を直接受ける高力ボルトの疲労強度 は極めて低いことが知られている文)。平滑鋼の場合, 引張強度が高くなれば, 疲労限注1)も高くなるが, ボル トの場合, 引張強度が高くなっても, 疲労限はほとんど 変わらない。たとえば, 引張強度 $100 \mathrm{kgf} / \mathrm{mm}^{2}$ の平滑 材の疲労限は $50 \mathrm{kgf} / \mathrm{mm}^{2}$ であるが，同じ強度のボルト の疲労限は $4 \mathrm{kgf} / \mathrm{mm}^{2}$ 程度である。この原因として, ボルトが切欠き材の一種であるという形状問題が挙げら れる。すなわち, 切欠き材では, 引張強度が高いと, 切 欠き感受性が高くなるため, 疲労限の低下が著しい。ま た, 荷重の伝達がボルトねじ山とナットねじ山の接触に よって行われることや，この時ボルトの第一ねじ山が大 きく荷重を受け持ち，ボルト各ねじ山の荷重分担が不均 一になり，片当たりや応力集中が起こりやすいという， 応力伝達機構の問題もある。

初期軸力を導入することなしに高力ボルトを使用する 接合の場合, ボルトとナットによる接合（以下, 中ボル 卜接合と呼ぶ）とシステムトラスにおけるボルトとノー ドによる接合（以下，システムトラス接合と呼ぶ）の間 には，荷重の伝わり方において差異がある。中ボルト接 合では，ボルトは引張力を受けて伸びようとするのに対 して，ナットは押されて縮まろうとする。このために第 一稀じに応力集中が生じる。これに対して, システムト ラス接合においては，鋼管部材の引張力は，ボルトを介 して,ノードに比較的スムーズに伝わる。この場合, ノ一 ドのねじ部は引張られるので, 応力集中が䌅和される(付 録参照)。また，システムトラスにおいては，ボルトの 強度に比べて，ナットに相当するノードの強度は一般的 に小さい。そのため，ノードのねじ部がミクロ的な接触 において降伏しやすくなり，片当たりに対してその部分 が塑性変形し, より広い面積で接触することになる。言 い換えると“なじみやすい”接合となり，ねじ部におけ る荷重分担の不均一が低減され，咸じ部の最大接触応力 が小さくなるはずである。これらのシステムトラス特有 の荷重伝達機構は疲労特性の向上につながると考えられ る。

以上述べたように，システムトラス接合には，中ボル 卜接合と, 荷重の伝わり方において差異がある。それゆ え, システムトラスの疲労特性を論じるにあたって, 中 ボルトの疲労特性からの推定にとよ゙まらず, システムト ラス接合としての疲労特性を正確に把握しておく必要が ある。本報告は，この観点にたち，太径ボルトを用いた システムトラス接合部をモデル化した実大試験体で疲労 試験を行い, システムトラスのボルトの疲労に関する
データを得たので，その分析とともに報告する。

\section{2. 試験体および実験方法}

\section{1 試験体のモデル化}

システムトラスの接合部注2)を再現するために，試験

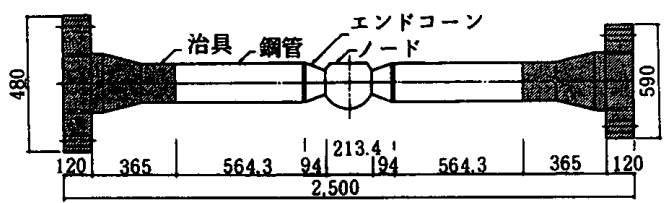

(a) 標準武駼体

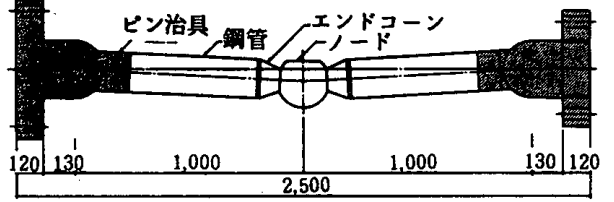

（b）鋼管部材間に角度をむたせて取付りた武倹体

図一2 試験体のモデル

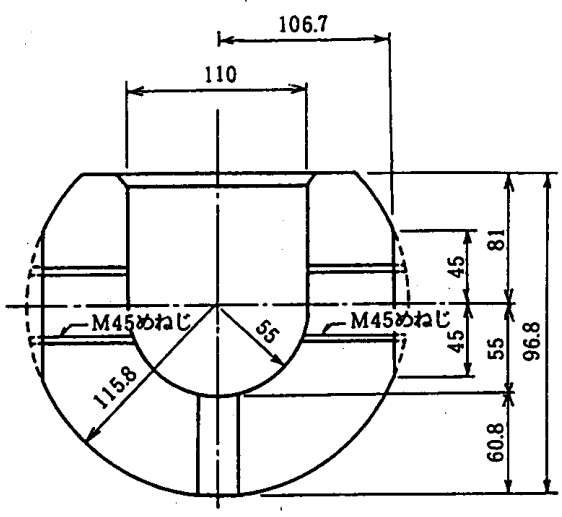

機城仕上げ程度：25 S以下

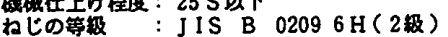

(a) ノード (N230)

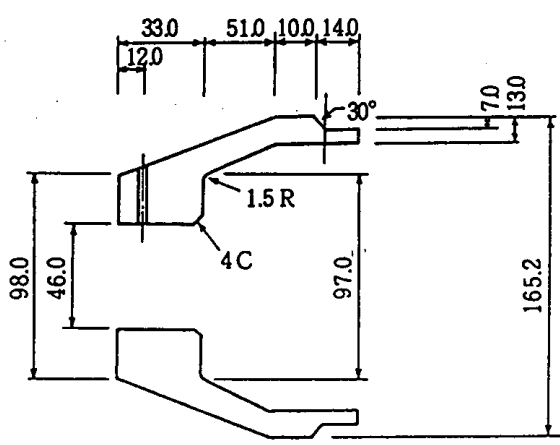

棫生上け程及：25 S以下

(b) エンドコーン (E165)

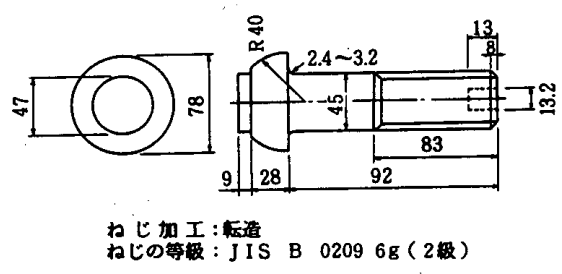

(c) ボルト (M45)

図一3 標準試験体 

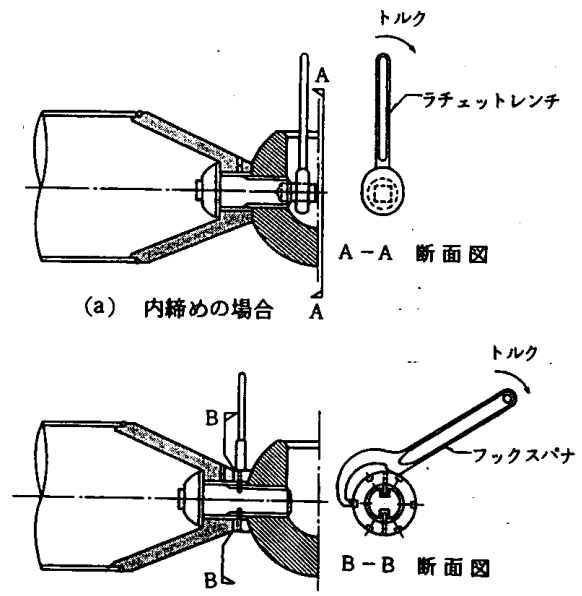

(b) 外楴めの堨合

图一4 ボルトの締め付け方法

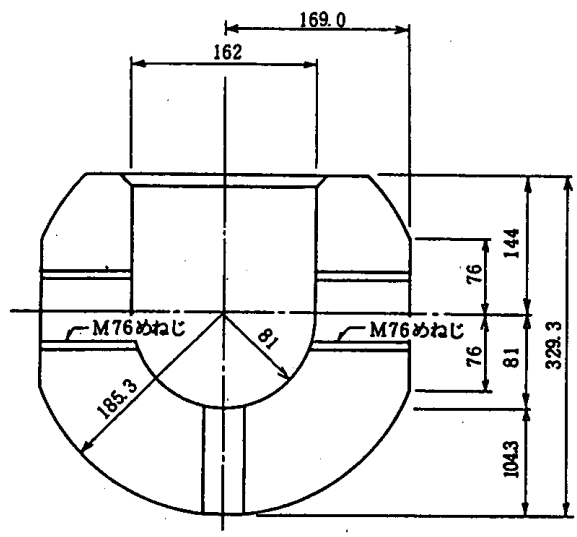

械什上げ程度：25 S以下

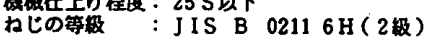

(a) ノード (N370)

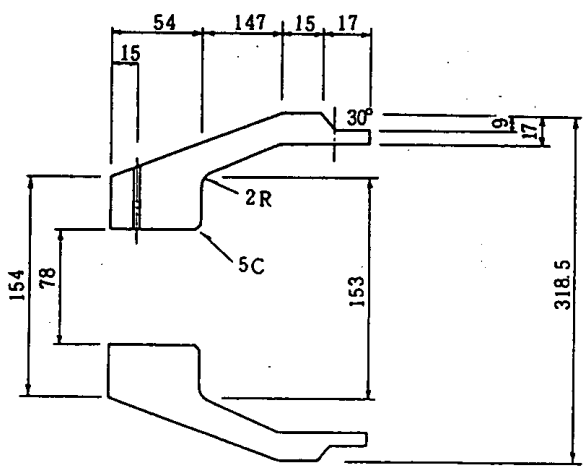

機械仕上げ程投：25 S以下

(b) エンドコーン (E 318)

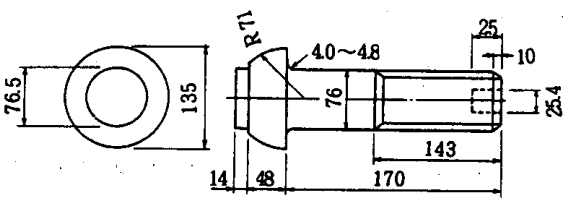

わじ加 $I:$ 切削

bしの等般：JIS B $02116 \mathrm{~g}$ (2)

(c) ボルト (M76)

図一5 部品寸法を大きくした武験体

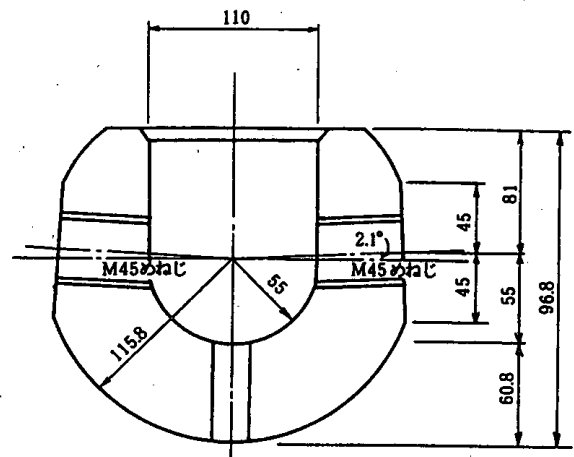

機械仕上げ程度：25 S以下 估しの等制 : J IS B $02096 \mathrm{H}$ (2极)

(a) ノード (N230T)

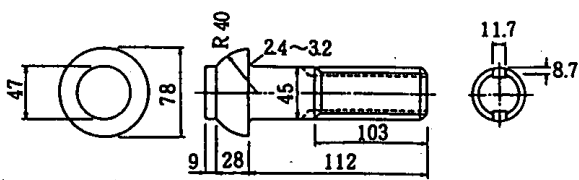

施じ加工：枟造

(b) ボルト (M45E1)

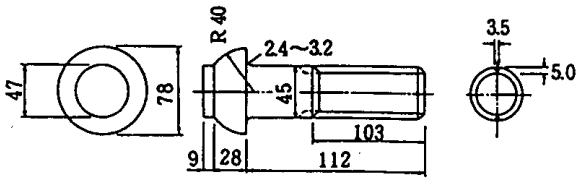

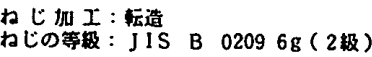

(c) ボルト (M45E2)

図一6 形状を変えた試験体

体として，図一2 に示すように，ノードの両端に鋼管部 材 (エンドコーン十鎘管) を，各々一本ボルトで接合し たモデルを考える。この鋼管部材に，引張力を与え，さ らに，一定の荷重振幅を与えて部分片振り引張繰返し載 荷を行う。

\section{2 試験体}

標準試験体として，図一3に示すようなノード，エン ドコーン，ボルトを考える。鋼管サイズは $\phi 165.2 \times$ 7.0 である。

標準試験体に対し，そのバリエーションとして，（1） 部品寸法を大きくした試験体，（2）ノードとエンドコー ンの間にワッシャを入れた試験体，（3）鋼管部材間に 角度をもたせて取付けた試験体，（4）ボルトの締め付 け方法を，図一4(a) に示すような内締めから，図一4(b) に示すような外締めに変えた試験体，（5）ボルトの材 質を変えた試験体，以上の 5 種類を用意する。これらす ベての試験体のボルトの締め付けは, スナッグタイトと する。これらの試験体を図一 5 と図一6に示す。また,ワッ シャを図一7に示す。

これらの試験体リストを表一1に示す。また，ボルト の機械的性質, 化学成分, 熱処理条件をそれぞれ表一2, 表一 3 ，表一 4 に示す。 
表一1＼cjkstart試験体リスト

\begin{tabular}{|c|c|c|c|c|c|c|c|c|c|c|c|c|c|}
\hline \multirow{2}{*}{ 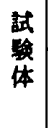 } & \multicolumn{3}{|c|}{, $-r$} & \multicolumn{2}{|c|}{ エンドコーン } & \multicolumn{2}{|c|}{ ボルト } & \multicolumn{2}{|c|}{ 管 } & \multicolumn{2}{|c|}{ ワッシャ } & \multirow{2}{*}{$\begin{array}{l}\text { 部材の } \\
\text { 取付き } \\
\text { 角度 }\end{array}$} & \multirow{2}{*}{$\begin{array}{l}\text { ボルト } \\
\text { の楼付 } \\
\text { 方法 }\end{array}$} \\
\hline & サイス & $\begin{array}{l}\text { エドリ-ンと } \\
\text { の接触面 }\end{array}$ & 材 共 & サイス & 材 質 & サイス & 材 賈 & \#1 & 材 質 & サイス & 材 質 & & \\
\hline 1 & N.230 & 平 面 & S M50A & E 165 & $\mathrm{~S} M 50 \mathrm{~A}$ & M45 & F10T相当 & $\phi 165.2 \times 7.0$ & S TK41 & - & - & $0^{\circ}$ & 内楴め \\
\hline 2 & $\mathrm{~N} 230$ & 平 面 & S M50A & E 165 & $\mathrm{SM} 50 \mathrm{~A}$ & M45 & F10T相当 & $\phi 165.2 \times 7.0$ & S TK4I & - & - & $0^{\circ}$ & 内楴め \\
\hline 3 & $\mathrm{~N} 230$ & 平 面 & $\mathrm{S} M 50 \mathrm{~A}$ & E 165 & S M50A & M45 & F10T相当 & $\phi 165.2 \times 7.0$ & S T K 41 & - & - & $0^{\circ}$ & 内楴め \\
\hline 4 & $\mathrm{~N} 230$ & 球 面: & $\mathrm{S} M 50 \mathrm{~A}$ & E 165 & $\mathrm{~S} M 50 \mathrm{~A}$ & M45 & PIOT相当 & $\phi 165.2 \times 7.0$ & S TK 41 & W45 & $\mathrm{S} 45 \mathrm{C}$ & $0^{\circ}$ & 内稀め \\
\hline 5 & $\mathrm{~N} 230$ & 球 面 & S M $50 A$ & E 165 & S M $50 \mathrm{~A}$ & M45 & F10T相当 & $\phi 165.2 \times 7.0$ & S TK 41 & W45. & $\mathrm{S} 45 \mathrm{C}$ & $0^{\circ}$ & 内粒的 \\
\hline 6 & $\mathrm{~N} 230$ & 球 面 & $\mathrm{S} M 50 \mathrm{~A}$ & E 165 & $\mathrm{SM} 50 \mathrm{~A}$ & M45 & $P 10 T$ 相当 & $\$ 165.2 \times 7.0$ & S TK 41 & W45 & $\mathrm{S} 45 \mathrm{C}$ & $0^{\circ}$ & 内楴的 \\
\hline 7 & $\mathrm{~N} 230$ & 球 面 & $\mathrm{S} M 50 \mathrm{~A}$ & E 165 & $\mathrm{~S} M 50 \mathrm{~A}$ & M45 & F10T相当 & $\phi 165.2 \times 7.0$ & S T K 41 & W45 & $\mathrm{S} 45 \mathrm{C}$ & $0^{\circ}$ & 内楴的 \\
\hline 8 & $\mathrm{~N} 230 \mathrm{~T}$ & 平 面 & SM50A & E 165 & $S \mathrm{M} 50 \mathrm{~A}$ & M45 & F10T相当 & $\phi 165.2 \times 7.0$ & S TK4l & - & $\mathrm{S} 45 \mathrm{C}$ & $2.1^{\circ}$ & 内缔的 \\
\hline 9 & $\mathrm{~N} 230 \mathrm{~T}$ & 球 面 & $\mathrm{S} M 50 \mathrm{~A}$ & E 165 & $\mathrm{~S} M 50 \mathrm{~A}$ & M45 & F10T相当 & $\phi 165.2 \times 7.0$ & S T K 41 . & W45 & $\mathrm{S} 45 \mathrm{C}$ & $2.1^{\circ}$ & 内締め \\
\hline 10 & $\mathrm{~N} 230$ & 球 面 & $\mathrm{S} M 50 \mathrm{~A}$ & E 165 & $S \mathrm{M} 50 \mathrm{~A}$ & M45E 1 & F10T相当 & $\phi 165.2 \times 7.0$ & S T K 4I & W45E 1 & $\mathrm{~S} 45 \mathrm{C}$ & $0^{\circ}$ & 外䋨的 \\
\hline 11 & $\mathrm{~N} 230$ & 球 面 & $\mathrm{SM} 50 \mathrm{~A}$ & E 165 & $\mathrm{~S} M 50 \mathrm{~A}$ & M45E 2 & F10T相当 & $\phi 165.2 \times 7.0$ & S T K 41 & W45E 2 & $\mathrm{~S} 45 \mathrm{C}$ & $0^{\circ}$ & 外橧め \\
\hline 12 & $\mathrm{~N} 230$ & 平面 & SM50A & E 165 & $\mathrm{~S} M 50 \mathrm{~A}$ & M45 & F 8T相当 & $\phi 165.2 \times 7.0$ & S T K 41 & - & - & $0^{\circ}$ & 内楴的 \\
\hline 13 & N 370 & 平 面 & $\mathrm{SM} 50 \mathrm{~A}$ & E 318 & $S M 50 A$ & M76 & F10T相当 & $\phi 318.5 \times 9.0$ & S T K4I & - & - & $0^{\circ}$ & 内楴的 \\
\hline
\end{tabular}

表一2 機械的性質

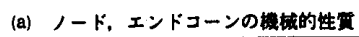

\begin{tabular}{|c|c|c|c|c|}
\hline 品名 & サ1X & 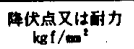 & $\begin{array}{l}\text { 引張㻆さ } \\
\mathrm{kB} / \mathbf{m}^{2}\end{array}$ & 伸U \\
\hline $1-1$ & N230 & 30以上 & 50以上 & 23以上 \\
\hline $1-F$ & N370 & 28以上 & 50以上 & 23以上 \\
\hline エンドコーン & $\varepsilon 165$ & 30以上 & 50以上 & 23以上 \\
\hline エンドコーン & E318 & 30以上 & 50以上 & 23以上 \\
\hline
\end{tabular}

(b) ボルトの機楜的性需

\begin{tabular}{|c|c|c|c|c|c|}
\hline 材 & 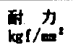 & 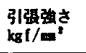 & 伸U & $\begin{array}{l}\text { 佼り } \\
.6\end{array}$ & ${ }_{\mathrm{H}} \mathrm{R}$ \\
\hline FIOT 柏当 & 90以上 & $100 \sim 120$ & 14以上 & 40以上 & $27 \sim 38$ \\
\hline$P B T$ 相当 & 64以上 & $80 \sim 100$ & 16以上 & 45以上 & $\mid B \sim 31$ \\
\hline
\end{tabular}

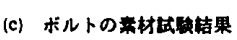

\begin{tabular}{|c|c|c|c|c|c|c|}
\hline \multirow{2}{*}{ 㚜 } & \multirow{2}{*}{$\begin{array}{l}\text { 讨 } \\
t \mathrm{t} / \mathrm{m}^{2}\end{array}$} & \multirow{2}{*}{ 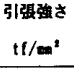 } & \multirow{2}{*}{ 伸ひ } & \multirow{2}{*}{$\begin{array}{c}\text { 校り } \\
\%\end{array}$} & \multicolumn{2}{|c|}{ 更むH R C } \\
\hline & & & & & 表面 & 内郡 \\
\hline 1 & 10.4 & 11.2 & 18 & 53 & 35 & 34 \\
\hline 2 & 10.3 & 11.0 & 18. & 54 & 35 & 34 \\
\hline 3 & 10.4 & 11.3 & 18. & 53 & 35 & 34 \\
\hline 4 & 10.5 & 11.4 & 19 & 54 & 35 & 34 \\
\hline 5 & 10.3 & 11.0 & I8 & 53 & 35 & 34 \\
\hline 6 & 10.3 & 11.2 & 18 & 54 & 35 & 34 \\
\hline 7 & 10.1 & 11.1 & 19 & 56 & 35 & 34 \\
\hline 8 & 10.5 & 11.1 & 17 & 52 & 33 & 33 \\
\hline 9 & 10.5 & 11.1 & 17 & 51 & 33 & 33 \\
\hline 10 & 10.6 & 11.1 & 17 & 53 & 34 & 34 \\
\hline 11 & 10.5 & 11.0 & 18 & 54 & 34 & 34 \\
\hline 12 & 7.5 & 9.2 & 20 & 57 & 27 & 27 \\
\hline 13 & 10.1 & 11.0 & 18 & 53 & 34 & 33 \\
\hline
\end{tabular}

\section{3 加力方法}

\section{(1) 加力装置}

実験は，横型 100 ton 疲労試験機を用いて行った。図 -8に示すように, ピットの中に全長約 $6.6 \mathrm{~m}$ の反力桁 を置き,この中に 100 ton 疲労試験機を設置した。次に， 試験体と試験機をボルト接合し，加力を行った。ただし， ノードと鋼管部材間に取付き角度を設けたものは，図一 8(b) に示すように, 試験体と試験機の間のピンを介し
表一3 化学成分

(a) ノード，エンドコーンの化学成分

\begin{tabular}{|l|l|l|l|l|l|}
\hline It 栚 & $\begin{array}{l}\mathrm{C} \\
\times 100\end{array}$ & $\begin{array}{l}\text { Si } \\
\times 100\end{array}$ & $\begin{array}{l}\mathrm{Un}_{\times 100} \\
\times 100\end{array}$ & $\begin{array}{l}\mathrm{P} \\
\times 1000\end{array}$ & $\begin{array}{l}\text { S } \\
\times 1000\end{array}$ \\
\hline SM 50A & 22以下 & 55以下 & 150以下 & 40以下 & 40以下 \\
\hline
\end{tabular}

(b) ポルトの化学成分

\begin{tabular}{|l|l|l|l|l|}
\hline 使用材料 & $\begin{array}{l}\mathrm{C} \\
\times 100\end{array}$ & $\begin{array}{l}\mathrm{Si} \\
\times 100\end{array}$ & $\begin{array}{l}\mathrm{Mn} \\
\times 100\end{array}$ & $\begin{array}{l}\mathrm{P} \\
\times 1000\end{array}$ \\
\hline SNCM 439 & $36 \sim 43$ & $15 \sim 35$ & $60 \sim 90$ & 30 以下 \\
\hline 使用材料 & $\begin{array}{l}\mathrm{S} \\
\times 1000\end{array}$ & $\begin{array}{l}\mathrm{Ni} \\
\times 100\end{array}$ & $\begin{array}{l}\mathrm{Cr} \\
\times 100\end{array}$ & $\begin{array}{l}\text { Mo } \\
\times 100\end{array}$ \\
\hline SNCM 439 & 30 以下 & $160 \sim 200$ & $60 \sim 100$ & $15 \sim 30$ \\
\hline
\end{tabular}

表一4 ボルトの熱処理条件

\begin{tabular}{|c|c|c|}
\hline 質 & $\begin{array}{c}\text { 焼入れ蕰度 } \\
{ }^{\circ}\end{array}$ & $\begin{array}{c}\text { 焼戻し昷度 } \\
{ }^{\circ} \mathrm{C}\end{array}$ \\
\hline F10T相当 & $830 \sim 880$ & $550 \sim 650$ \\
\hline F 8T相当 & 860 & $630 \sim 650$ \\
\hline
\end{tabular}

て加力した。

写真一1 に試験機および試験体 5 を示す。

(2) 加力条件

図一9に示すように，武験体に，M45 ボルトの長期 許容軸力 $N_{a l}$ に相当する平均引張荷重 $P_{\text {mean }}$ を中心に片 振幅荷重 $P_{a}$ の繰返し荷重を与える注3)。

$$
\begin{aligned}
& N_{a l}=A \sigma_{a l} . \\
& P_{\text {mean }}=N_{a l} \\
& P_{a}=A \sigma_{a} \cdots
\end{aligned}
$$

ここで， $A=15.904 \mathrm{~cm}^{2}$ (M 45 ボルトの軸断面積)

$\sigma_{a l}=31 \mathrm{kgf} / \mathrm{mm}^{2}$ (ボルトの長期許容応力度 ${ }^{\text {住4 }}$ )

$\sigma_{a}:$ 表一 5 の片振幅荷重欄の（）内の数值 (応 力度振幅)

このとき, 最大引張荷重 $P_{\text {max }}$ および最小引張荷重 


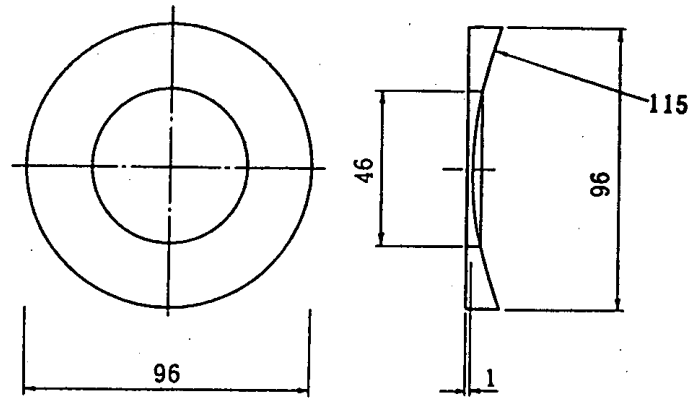

機械仕上げ程度：25 S以下

(a) ワッシャ (W45)

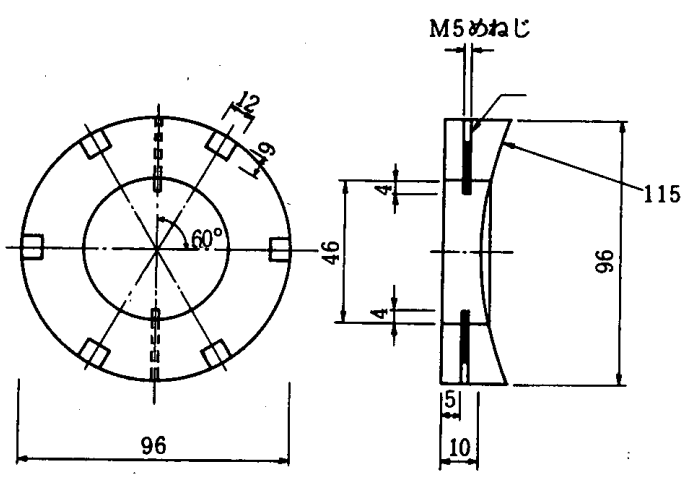

機械仕上げ程度：25 S以下

(b) ワッシャ (W45E 1)

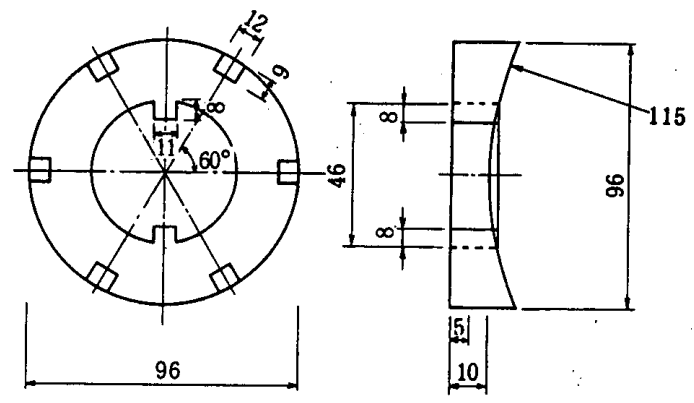

機械仕上げ程度：25 S以下

(c) ワッシャ (W45E2)

図一7 ワッシャ

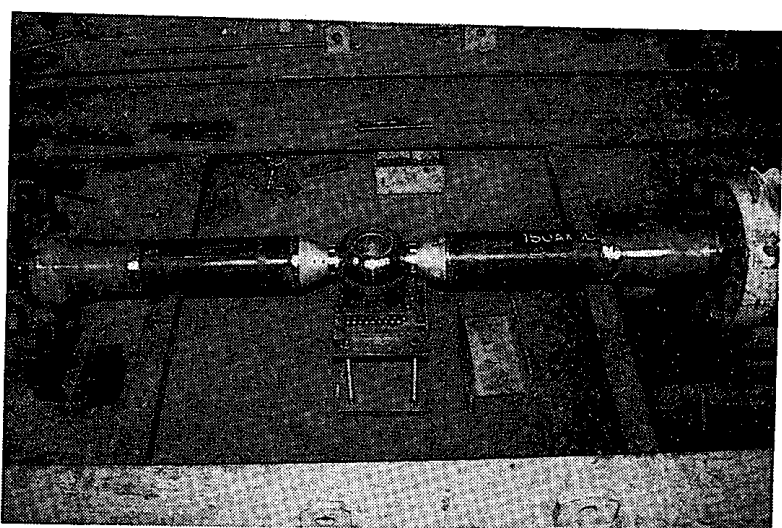

写真一1試験機および試験体 5

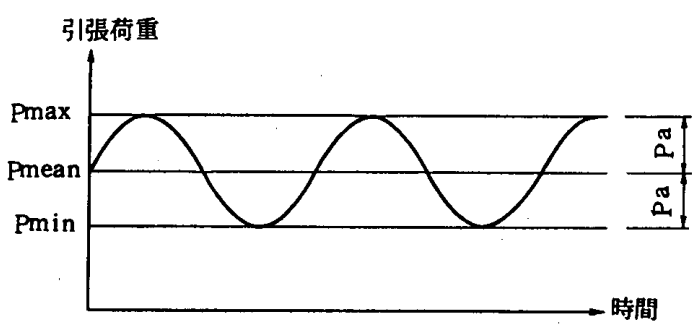

Pmean：平均引㝿荷重

Pmax ：最大引張荷重；Pmean + Pa

Pmin ：最小弓張荷重； Pmean - Pa

$\mathrm{Pa} \quad$ : 片振㷎倚重

図一9 加力パターン

$P_{\min }$ は, 次式のようになる。

$$
\begin{aligned}
& P_{\max }=P_{\text {mean }}+P_{a} \\
& P_{\min }=P_{\text {mean }}-P_{a}
\end{aligned}
$$

表一 5 に平均引張荷重, 片振幅荷重, 最大引張荷重, 最小引張荷重および繰返しのサイクルを示す。

\section{3. 実験結果}

3.1 破壊状況

疲労破壊はすべてノード端面位置のボルトにおいて生 じている。一般的に, 中ボルトの破断は, ナット端面, 不完全ねじ部, 首下丸み部 の三箇所のうち，いずれかにおいて生じ るものである。本実験におけるノード端 面でのシステムトラスのボルトの破壊 は，中ボルトのナット端面での破壊に相 当し，ボルトの疲労破壊性状としては, 特異な性状を示していない。これらの結 果より，今回のようなシステムトラスに おいては，ノード，エンドコーンには疲 労破壊は発生せず，ボルトの疲労強度が システムトラスの接合部としての疲労強 度になることが確認された。

図一10 および写真一 2 に試験体 5 の破 壊状況を示す。

図一-8 疲労試験機および試験体 
表一 5 加力条件

\begin{tabular}{|c|c|c|c|c|c|c|}
\hline 藏 & 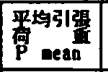 & 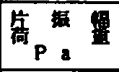 & 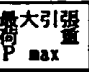 & 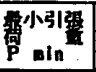 & 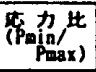 & $\$ 19 n$ \\
\hline 1 & 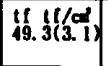 & 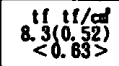 & 57.6 & $41.0^{t 1}$ & 0.712 & 5.0 \\
\hline 2 & $3(3.1)$ & \begin{tabular}{|l|l|}
$16.4(1.03)$ \\
$\langle 1.25\rangle$
\end{tabular} & 65.7 & 32.9 & 0.501 & 5.0 \\
\hline 3 & $49.3(3.1)$ & $\begin{array}{l}24.7(1.55) \\
\langle 1.89\rangle\end{array}$ & 74.0 & 24.6 & 0.332 & 5.0 \\
\hline 4 & $49.3(3.1)$ & $\begin{array}{l}6.4(0.4) \\
<0.49>\end{array}$ & 55.7 & 8 & .770 & 5.0 \\
\hline 5 & $49.3(3.1)$ & $\begin{array}{l}9.5(0.6) \\
<0.73>\end{array}$ & 58.8 & 39.8 & 0.677 & 5.5 \\
\hline 6 & $49.3(3.1)$ & $\begin{array}{l}16.4(1.03) \\
\langle 1.25\rangle\end{array}$ & 64.7 & 32.9 & 0.501 & 4.0 \\
\hline 7 & $49.3(3.1)$ & \begin{tabular}{|c|}
$24.7(1.55)$ \\
$<1.89\rangle$ \\
\end{tabular} & 74.0 & 24.6 & .332 & 3.5 \\
\hline 8 & $|49.3(3.1)|$ & \begin{tabular}{|r|}
$16.4(1.03)$ \\
$\langle 1.25\rangle$ \\
\end{tabular} & 65.7 & 2.9 & .501 & 3.5 \\
\hline 9 & $\mid 49.3(3.1)$ & $\begin{array}{r}6.4(0.4) \\
\langle 0.49>\end{array}$ & 55.7 & 29 & .770 & 5.0 \\
\hline 10 & $49.3(3.1)$ & \begin{tabular}{|c|}
$24.7(1.55)$ \\
$\langle 1.91>$ \\
\end{tabular} & 74.0 & 24.6 & 0.332 & 5.0 \\
\hline 11 & $\mid 49.3(3.1)$ & $\begin{array}{l}6.4(0.4) \\
\langle 0.54\rangle\end{array}$ & 55.7 & 42.9 & 0.770 & 5.5 \\
\hline 12 & $39.8(2.5)$ & \begin{tabular}{|r|}
$19.9(1.25)$ \\
$<1.52\rangle$ \\
\end{tabular} & 59.7 & 18.9 & 0.332 & 5.0 \\
\hline 13 & 49. $8(1.1)$ & $\begin{array}{l}46.7(1.03) \\
\langle 1.20> \\
\end{array}$ & .6 & 3.2 & .033 & 5.0 \\
\hline
\end{tabular}

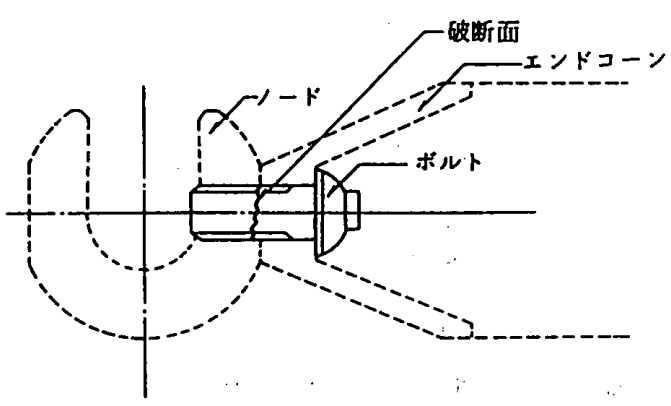

図一10破壊状況

表 $6 N$ 数および破壊状況

\begin{tabular}{|c|c|c|}
\hline 嫣駰体 & $\mathrm{N}$ 数 & 咉 状 识 \\
\hline 1 & 534. 154 回 & ボルト破断 \\
\hline 2 & 59, 252 回 & $"$ \\
\hline 3 & 21.951 回 & $"$ \\
\hline 4 & 1.750,000回 & 破俵せず \\
\hline 5 & 487.390 回 & ボルト破断 \\
\hline 6 & 191.372 回 & $"$ \\
\hline 7 & 25,850 回 & $"$ \\
\hline 8 & 44, 137 回 & $"$ \\
\hline 9 & 2.000.000回 & 破断せず \\
\hline 10 & 34.672 回 & ボルト破断 \\
\hline 11 & 821.252 回 & $"$ \\
\hline 12 & 35.328 回 & $"$ \\
\hline 13 & 303.579 回 & ボルト破断 \\
\hline
\end{tabular}

\section{$3.2 N$ 数}

表一6に，各試験体の $N$ 数および破壊状況を示す。

\section{4. 実験の考察}

\section{$4.1 S-N$ 図}

システムトラスのボルトの疲労特性を明らかにするた
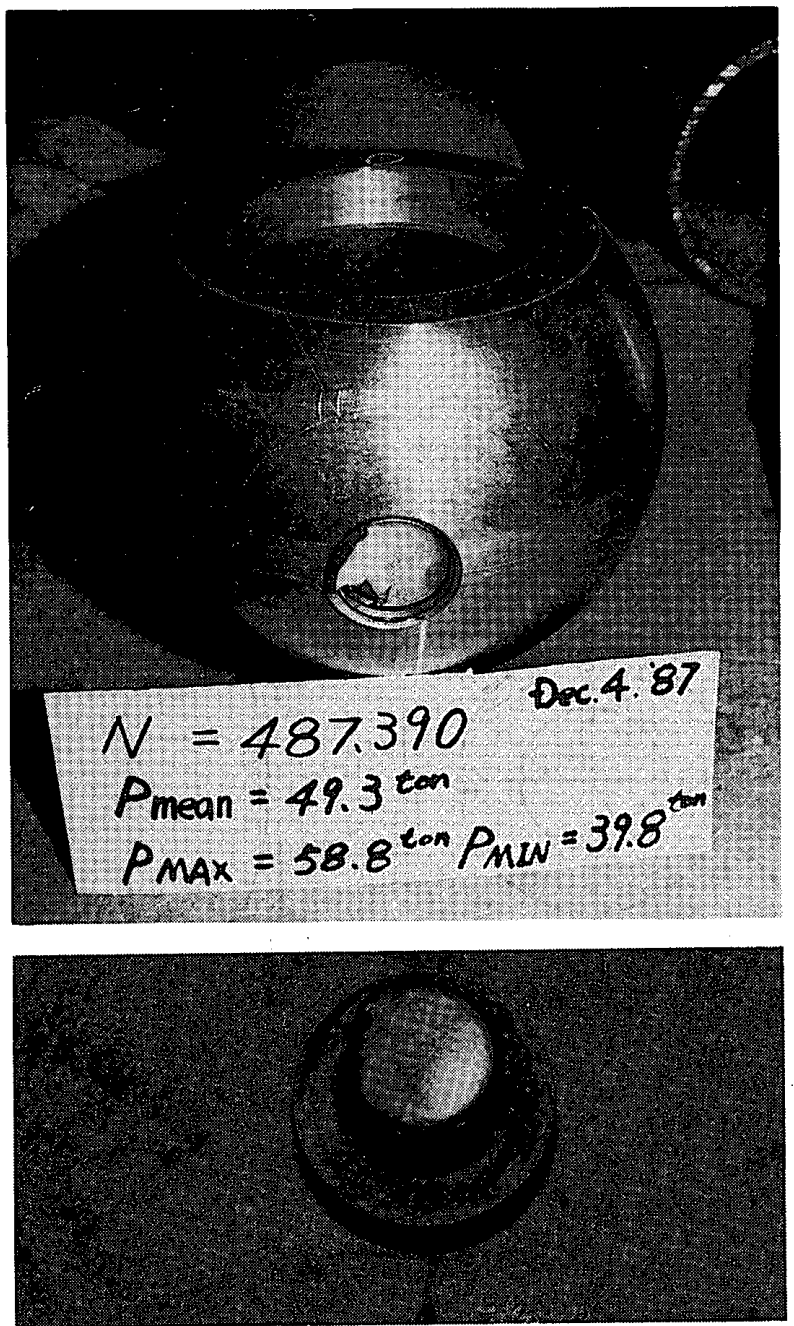

武験体 5

㝍真一2 破壊状況

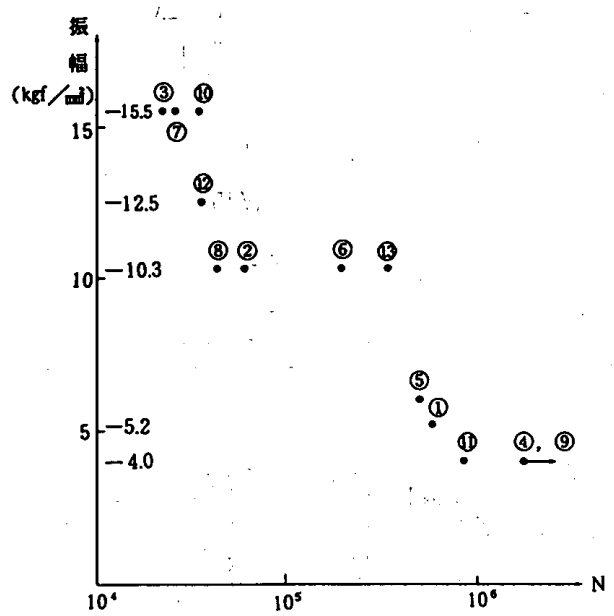

图一11 片対数 $S-N$ 図

め, 実験結果より $S-N$ 図を求める。図一11に片対数 $S-N$ 図を，図一12に両対数 $S-N$ 図を示す。片対数 $S-N$ 図を用いると結果のばらつきが大きくなるので, 考察には，両対数 $S-N$ 図を採用する。

4.2 疲労強度に影響を与える要因

(1) 寸法効果

一般的に，鋼構造部材の疲労破損における寸法効果之 


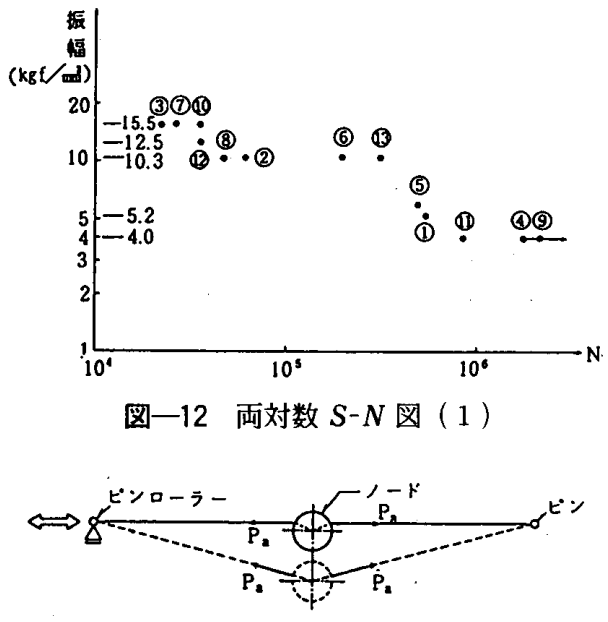

图一13 組み合わせ荷重状態

して, 大きさが倍になると, 疲労限の $10 １ 5 \%$ の低下 があると言われている抆。しかし，今回の実験におい ては, 同じ応力度振幅とした試験体 2 と 6 と 13 の図一 16 に示す結果から分かるように，M 45 とM76 ボルトの 比較に関する限り, 寸法効果による疲労強度の低下は特 に認められない。今回の実験では，逆にM76ボルトの 疲労強度の方が大きいという結果がでており, 寸法効果 による悪い影響は生じているい。

寸法効果による疲労強度の低下がないことは，高力ボ ルトを中ボルト接合として行った実験文)においても報 告されている。

\section{(2) ワッシャの影響}

ノードとエンドコーンの間にワッシャを入れた場合の 影響については，試験体 2 と 6 , および試験体 3 と 7 の それぞれの結果から分かるように，ワッシャを入れた方 が疲労強度が大きくなっている。これは, ワッシャに $R$ 面があるため, ワッシャの微小移動とワッシャの弾 性変形によるなじみに起因すると考えられる。

\section{（3.）鋼管部材間の取付き角度}

鋼管部材間に取付き角度を設けたものは，図一13に 示すような加力状態にあると考えられる。角度として， エンドコーン穴とボルトのクリアランス $30 / 1000$ に相 当する 2.1 度を採用した。この角度は, 製作誤差, 組立 誤差等の集積で起こりえる最大角度の 3 倍である文3)。 試験体 8 と 9 それぞれのボルトの縁応力度は, 鋼管部材 間の取り付き角度による曲げ応力が付加されるために, 增加していると考えられる。しかし，ボルトの疲労強度 はほとんど低下していない。

\section{（4）締め付け方法}

試験体 3 と 7 と 10 の比較によると，ボルトを外楴め した試験体 10 の疲労強度が最も大きいことが分かる。 一方, 試験体 4 と 11 の比較では, 外締めの試験体 11 の 疲労強度は小さい。この結果の差異は, 図一14 に示す ように，外楴めに必要な楴め付け用の溝によるボルトの

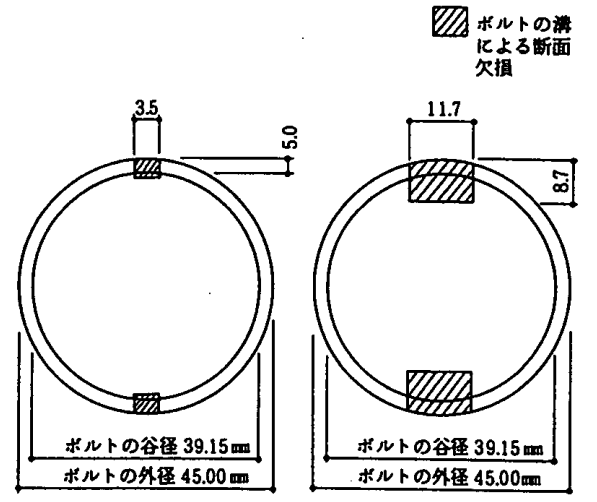

(a) 出诤体 10

(b) 出锁体 11

图-14 ボルトの断面欠損

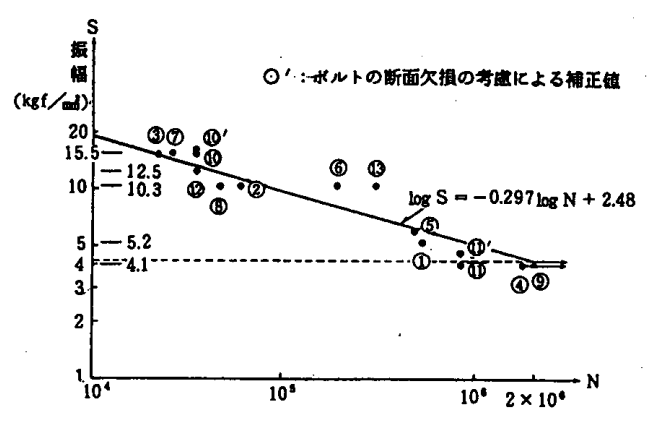

図-15 両対数 $S-N$ 図 (2) と $S-N$ 線図

断面欠損に起因していると考えられる。試験体 10 の斬 断面の欠損は， $0.35 \mathrm{~cm}^{2}$ であり，欠損率は $2 \%$ である， これに対して，試験体 11 では，軸断面の欠損は 1.98 $\mathrm{cm}^{2}$ ，欠損率としては $12 \%$ である。よって，試験体 11 と 11 の軸断面欠損を考慮した軸部応力度は, 各々 15. \& $\mathrm{kgf} / \mathrm{mm}^{2}$ と $4.5 \mathrm{kgf} / \mathrm{mm}^{2}$ となる。図一15にこれらの㬋 により補正した，両対数 $S-N$ 図を示す。この図から分 かるように，締付け用の溝によるボルトの断面欠損を 考慮した応力度によって評価すると，他の試験体に比へ て疲労強度の低下は認められない。締め付け用の溝によ る切欠き効果は，特に考慮する必要はないと言える。

(5) 材 質

表一1に示すように，今回の実験においては F $10 \mathrm{~T}$ を 標準として用いたが，試験体 12 にはF $8 \mathrm{~T}$ 相当の鋼材を 用いた。図一15 から分かるように，試験体 12 の疲労強 度は, 他の試験体の疲労強度に比べて, 特に大きな差異 は認められない。この傾向は, SCM 4, SNCM 5, $\mathrm{S} 20 \mathrm{C}, \mathrm{SNC} 2$ 等の材質のボルトについての実験文にに おいても，同様に報告されている。

\section{$4.3 S-N$ 線図および疲労限}

図一 15 にある直線は疲労強度の試験結果を最小 2 乗 法で整理した $S-N$ 線図である。文5）と文 8）を参照 して，この $S-N$ 線図を数式表示すると，次式のように なる。

$\log S=-0.297 \log N+\dot{2} .48$

ここで, $S$ の単位は $\mathrm{kgf} / \mathrm{mm}^{2}, N$ は回数である。 


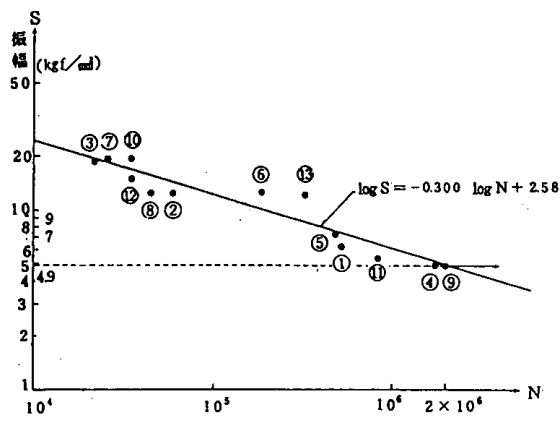

図一16 有効断面積の応力度による $S-N$ 図および $S-N$ 線図

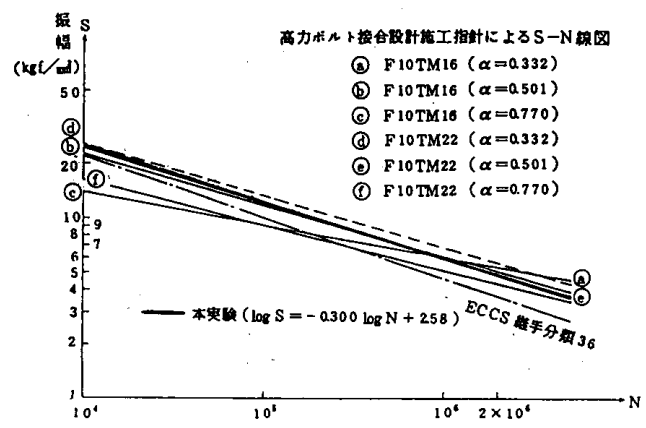

図一17 有効断面積の応力度による $S-N$ 線図の比較

4.2 節の（ 2 ）.で述べたように，ノードとエンドコー ンの間にワッシャがある場合とない場合との疲労強度の 差異は明らかであるので, 個別に $S-N$ 線図を示すこと も考えられる。しかし，今回の実験の試験体母数は少な く，高い精度の $S-N$ 線図を得ることは難しいこと，お よび， $S-N$ 線図の数式表示の目的は，システムトラス の疲労設計の目安として用いやすいものにすることを考 えて,一つの式で表示した。

注 1) で述べたように, 疲労限を $2 \times 10^{6}$ 回の応力の繰 り返しに耐え得る最大応力度振幅とすると，（6）式の $S-N$ 線図より，疲労限は $4.1 \mathrm{kgf} / \mathrm{mm}^{2}$ となる。

次に, Recommendations for the Fatigue Design of Steel Structures 文01 および高力ボルト接合設計施工指 針文11)に定めているボルトの疲労強度と比較するため, ボルトの有効断面積注5)を用いて求めた応力度による両 対数 $S-N$ 図を図-16に示す。各試験体の有効断面積の 応力度は表一 5 に示している。図一16 中の直線は, 最小 2 乗法による $S-N$ 線図である。これを数式表示すると, (7) 式のようになる。

$\log S=-0.300 \log N+2.58$

ここで, $S$ の単位は $\mathrm{kgf} / \mathrm{mm}^{2}, N$ は回数である。

（7）式より, 有効断面積で表した疲労限は $4.9 \mathrm{kgf} /$ $\mathrm{mm}^{2}$ である。

高力ボルトを用いて中ボルト接合した場合の, 文 10) の継手分類 36 に示されている $S-N$ 線図と文 11$)$ のデー 夕から作成した $S-N$ 線図をそれぞれ図一17 に示す。文 11）から得られる $S-N$ 線図の作成は，表一 5 に示す応 力比のうちで代表的なものを選び出し，表一7 の換算表
表一7 F 10 TM16, F 10 TM22 の $S-N$ 線図

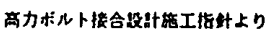

$\log \mathrm{S}=\mathrm{K} \log \mathrm{N}+\mathrm{C}$

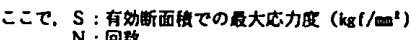

\begin{tabular}{|c|c|c|c|c|}
\hline \multirow{2}{*}{$\begin{array}{c}\text { 加化 } \\
a\end{array}$} & \multicolumn{2}{|c|}{ F10TM16 } & \multicolumn{2}{c|}{ F 10TM22 } \\
\cline { 2 - 5 } & $\mathrm{K}$ & $\mathrm{C}$ & $\mathrm{K}$ & $\mathrm{C}$ \\
\hline 0.332 & -0.2884 & 3.0366 & -0.2978 & 3.0564 \\
0.501 & -0.2922 & 3.2252 & -0.2735 & 3.0269 \\
0.770 & -0.1809 & 2.8098 & -0.2488 & 3.1471 \\
\hline
\end{tabular}

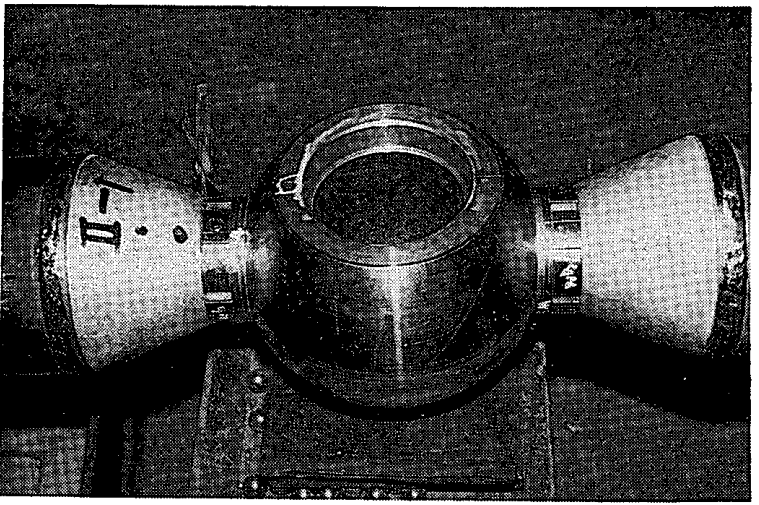

写真一3 平均引張荷重時における肌隙状況

に基づき行った。これらの $S-N$ 線図は, $95 \%$ 信頼下 限值である。

図一17より，本実験より得られた $S-N$ 線図は, 中ボ ルト接合の結果文(10), 文11) と同じような傾向を示している ことが分かる。システムトラス接合は, 中ボルト接合に 比べて, 付録で述べているように弾性解析の結果では応 力集中が少ないにもかかわらず, 疲労強度においては大 きな差異が認められない。

\section{4 ボルトの締結状況}

ここで行った実験においては, 試験体に平均引張荷重 を与えた状態において，エンドコーンとノードとの間に $0.2 \mathrm{~mm}$ から $0.3 \mathrm{~mm}$ の肌隙が生じている。写真一 3 に 試験体 5 の平均引張荷重時における肌隙の状況の一例を 示す。これは，序文でも述べたように今回のようなシス テムトラスの接合では,高力ボルト引張接合とは異なり， 材間圧縮力は存在せず，ボルトで直接に力を受け持って いることを意味している。そのため，外力の変動はすべ てボルトにも伝わっていると考えられる。

\section{5 設計への提言}

システムトラスのボルトの疲労限は軸断面積の応力度 で $4.1 \mathrm{kgf} / \mathrm{mm}^{2}$ であり, 有効断面積で $4.9 \mathrm{kgf} / \mathrm{mm}^{2}$ で ある。この疲労限はF10T高力ボルトの引張強度が有効 断面積で $100 \mathrm{kgf} / \mathrm{mm}^{2}$ であるさとを考えると, 極めて 小さい。ここで扱っているシステム゙トラ゙スのボルトの長 期許容応力度は, $31 \mathrm{kgf} / \mathrm{mm}^{2}$ であり,この值に比べても, $13.2 \%$ である。このようなことから, 疲労が問題とな るような構造物への, システムトラスの適用に際しては, 
建物の使用寿命の設定，その期間にボルトに生じる応力 の繰り返し数や応力度振幅などを考慮し，本報告で数式 表示した $S-N$ 線図を参考にしつつ，慎重な構造検討を すべきである。さらに，鋼管部材が直接に風を受けるよ うな構造物へのシステムトラスの適用に際しては，鋼管 部材の個材振動文121がボルトに繰返し応力を生じさせる 場合もあるので，設計にあたって疲労問題を考慮すべき である。

\section{6. 結 論}

太径ボルトを用いたシステムトラス接合としての疲労 特性を把握するための実験を行い，以下のことを明らか にした。

（1）今回のようなシステムトラスにおいては，ノード やエンドコーンでは疲労破壊は生ぜず，ボルトの疲労強 度がシステムトラス接合部の疲労強度となる。

（2）ここで扱ったシステムトラス接合の疲労限は，軸 断面積において $4.1 \mathrm{kgf} / \mathrm{mm}^{2}$, 有効断面積において 4.9 $\mathrm{kgf} / \mathrm{mm}^{2}$ である。

（3）部品サイズを大きくした試験体によっても，また ボルトの材質を変えた試験体によっても疲労特性に大き な差異はない。

（4）ノードとエンドコーンの間にワッシャを入れた試 験体の疲労強度は向上している。

（5） ボルトに断面欠損がある場合の疲労強度は，それ によるボルトの応力度の増加を考慮すれば，標準的なも のから算定できる。

（6）鋼管部材を, 誤差等の集積で実際に起こりうる角 度の 3 倍にして取付けた場合, ボルトの縁応力度は増加 しているにもかかわらず，ボルトの疲労強度はほとんど 低下しない。

（7）試験体に引張荷重を与えた状態において，エンド コーンとノードとの間に肌隙が生じることからして， シ ステムトラス接合では, 変動軸力はボルトに直接に伝わ る。

（8）今回の実験により得られた $S-N$ 線図は，システ ムトラスの疲労設計に際して，目安となりえる。

\section{謝 辞}

本研究に際し，懇切丁寧な御指導を頂いた東京工業大 学名誉教授・神奈川大学教授藤本盛久博士に深く感謝致 します。また，貴重な御助言を頂いた新日本製鉄株式会 社西田新一博士に深く感謝致します。

付 録 ボルト接合部の応力の流九を把握するための弾性解析 中ボルト接合とシステムトラス接合における忘力伝達機構の 差異を明らかにするため，軸対称有限要素法による弾性解析を 行った。それぞれのボルト接合部の解析モデルを図一付 1 に示 す。

\section{付 1 解析法}

解析法は一般的な有限要素法であるが，三角形は 6 節点，四 角形は 8 節点の要素内で変化するひずみ分布を表現できる高次 要素を用いる。

ねじ部の笅密な応力集中の問題を扱っている研究文(3)ー文16)は 多くみられ，非常に細かい分割を行っているが，ここでは各的 じ山を通して伝達される応力の分布を求めることが目的である ので，中程度の要素分割とした。しかしながらここで用いて いる高次要素は，一般の 3 節点三角形要素に置換すると，4 倍 の分割密度に相当する。
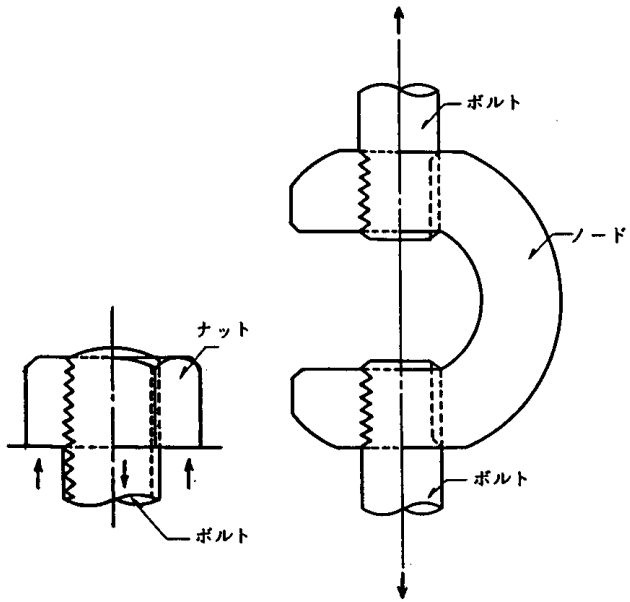

图一付 1 ボルト接合部

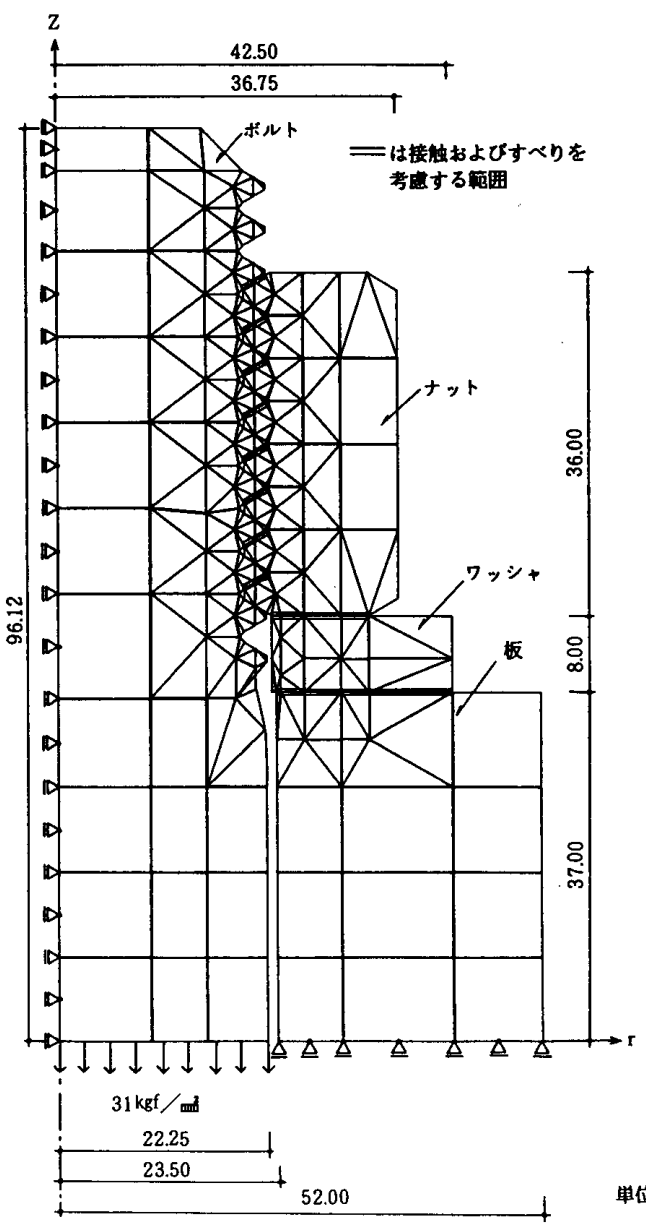

(a) 中ボルト接合

図一付 2 要素分割図 


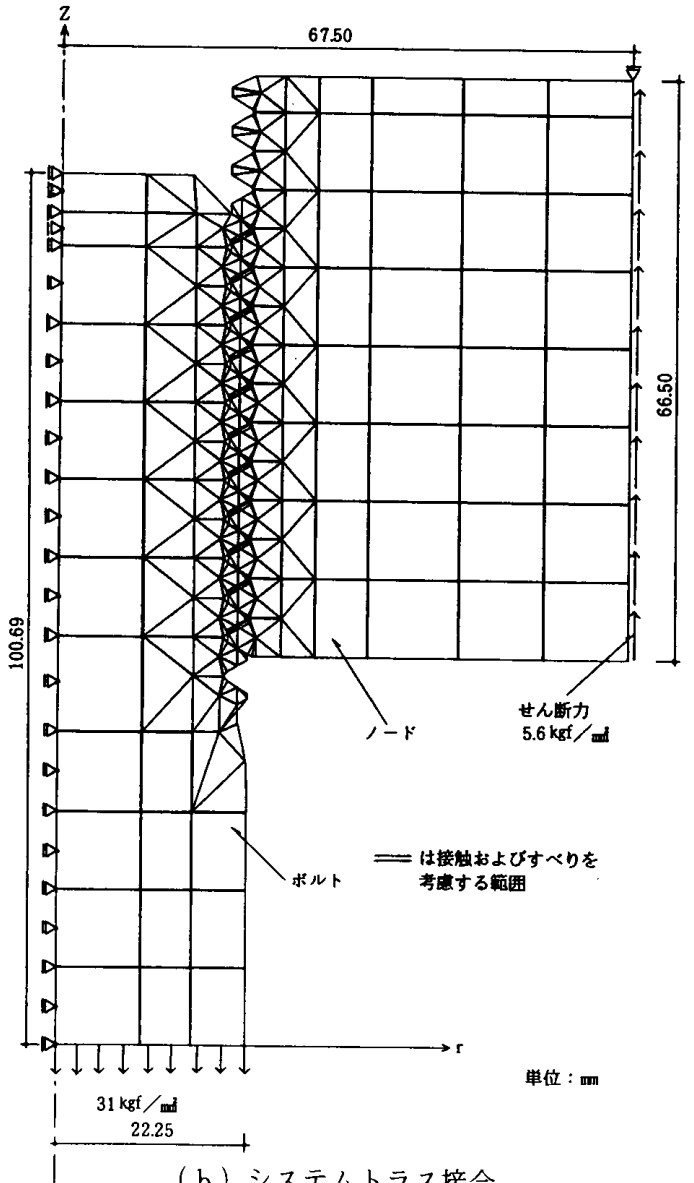

(b) システムトラス接合

図一付 2 要素分割図

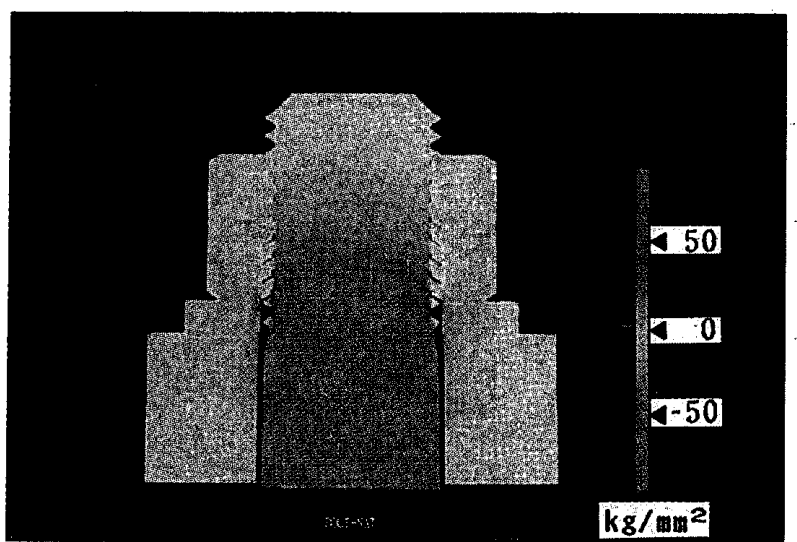

(a ) 中ボルト接合

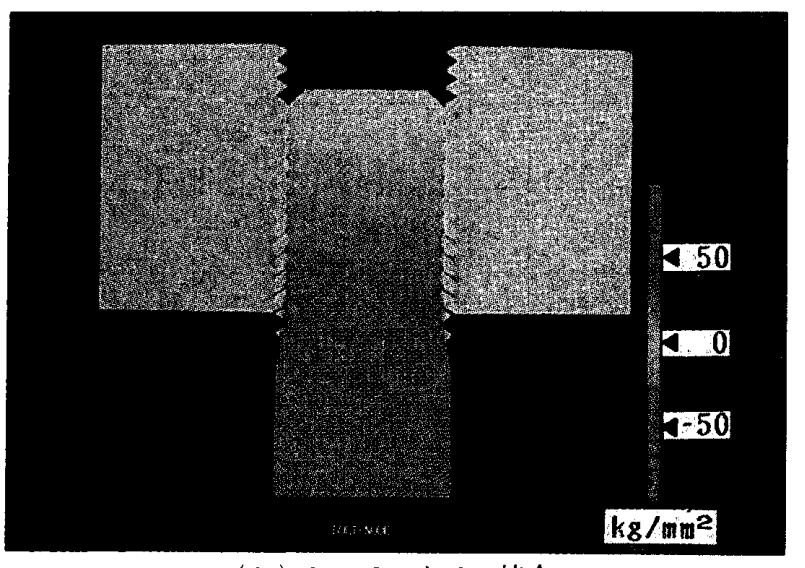

(b) システムトラス接合

図一付 3 軸方向応力度 $\left(\sigma_{z}\right)$ の分布 
ボルトのねじ部では，接触する面と離間する面があり，接触 している面は面に沿って滑ることが考えられる。この部分のモ デル化については, 文13）を参考に雄ねじと雌ねじの接触, 離 間および滑りを考慮できるように解析を行う。接触する部分は 雄的じ側と雌ねじ側に別々の節点番号を付ける。この部分の $r$ 方向（対称軸回り半径方向）の変位 $u, z$ 方向（軸対称方向） の変位 $w$ を, 各々 $z=0$ の面に対して角度が $\alpha$ の滑り面に沿っ た方向の変位 $s$, 法線方向の変位 $c$ へ変換する。この面におけ る摩擦係数はゼ口と考え，雄的じと雌的じの対応する節点間に おいて， $c$ は同一変位を生じ, $s$ は独立に変位するように解析 を行う。

\section{付 2 解析モデル}

図一付 2(a) に中ボルト接合の場合の要素分割と外力，支持 条件を示す。外力としてボルト軸部に, ボルトの長期許容応力 度に相当する, 等分布荷重 $31 \mathrm{kgf} / \mathrm{mm}^{2}$ 作用させる。支持条件は, ボルトに締め付けられている板の中央水平面を水平ローラーと する。接触して滑る部分は, ボルトとナット間のねじ山部分,ナッ トとワッシャ間, ワッシャと板の間である。ボルトとナットの かん合長さは, ボルトの呼び径の 0.8 倍である。ここで解析す るM45 の場合 $36 \mathrm{~mm}$ である。

図一付 2(b) は，システムトラスの場合を示している。ボル トのかん合長さは、ボルトの呼び径の 1.1 倍である。外力条件 は先と同様である。支持条件は中ボルト接合のものと異なる。 雌ねじ側の外周面に鉛直方向のせん断力を上向きに分布させ， 反力が滑らかにノード側に伝達されるようにしている。

\section{付 3 解析結果}

図一付 3 に両モデルの $z$ 方向応力度 $\sigma_{z}$ の分布を示す。この 図は高解像グラフィックディスプレイを用いて；有限要素法の 結果を表示したものである。青が正の応力度, 赤が負の応力度 を示している。表現を分かりやすくするため, 対称軸の反対側 も同様に示し, 妇じ部の接触, 離間状洗を分かりやすくするため, 変形を 6 倍に拡大している。

中ボルト接合では，ボルトに引張応力が生じ，ナット，ワッ シャ, 板に圧縮応力が発生していることが分かる。ねじ部から 徐々に引張力がナット側に伝達されるため, ボルトの応力度が 上部ほど小さくなっている。ナットに生じる圧縮応力度は, 上 部は小さく，下部ほど大きい。一方，システムトラス接合では， ノード側での力の行き先が中ボルト接合の場合と異なるため, ボルトの引張力が滑らかにノードに伝達されていることが分か る。

図一付 4 に両モデルのせん断応力度 $\tau_{r z}$ の分布を示し，ねじ 山部分を介して伝達される力の分布を比較する。中ボルト接合 では，第 1 ねじ山の部分に最大 $\tau_{r z}=47.1 \mathrm{kgf} / \mathrm{mm}^{2}$ のせん断応 力度が集中しているが，システムトラス接合においては，最大 $\tau_{r z}=38.7 \mathrm{kgf} / \mathrm{mm}^{2}$ である。またせん断応力度の平均值につい ても，システムトラス接合の方が小さいことも分かる。

図一付 5 に，鋼材の降伏条件を表す von Mises の式によって 求めた，相当応反度 $\sigma_{g}$ の分布を示す。図一付 3 および図一付 4 と同様に, 中ボル卜接合の最大 $\sigma_{g}=95.2 \mathrm{kgf} / \mathrm{mm}^{2}$ の相当応力度 に比べ, システムトラス接合の最大 $\sigma_{g}=81.2 \mathrm{kgf} / \mathrm{mm}^{2}$ は小さく, また, 相当応力度の分布も滑らかであることが分かる。これらは， 応力の伝達する方向が中ボルト接合におけるボルトとナットの 場合と，システムトラス接合におけるボルトとノードの場合で 異なっていること，および，かん合長さをボルトの呼び径の
0.8 倍から 1.1 倍に長くした効果であると考えられる。

以上の結果より, システムトラスのボルト接合は, 中ボルト 接合に此べて, ボルトねじ部の応力の流れが滑らかで, 応力集 中もないことが明らかである。

注

1) 疲労限

疲労限とは無限の繰り返しに耐える最大応力度のことで ある。部分片振り引張りの場合,一般的には, 疲労限は 応力度振幅 $\sigma_{a}$ と平均応力度 $\sigma_{m}$ との和 $\sigma_{a}+\sigma_{m}$ で表示すへ きである。しかし, ボルトの場合, 平均応力度 $\sigma_{m}$ の疲労 に与える影響が比較的小さく, かつ平均応力度を一定の まま使用するとは限らないので, 応力度振幅だけで比較 した方が理解しやすい。そのため, 本論文では, 応力度 振幅 $\sigma_{a}$ をもって, 疲労限とする。

従来, 疲労の実験上の制約から, 無限の絽返し数として, $2 \times 10^{6}$ 回をもって代表されてきていたが，疲労に対する 最近の考え方站)による之， $2 \times 10^{6}$ 回の応力綝返し数に対 応する基本応力範囲を, $2 \times 10^{6}$ 基本許容応力範囲之定め, $1 \times 10^{8}$ の繰返しにおける最大の応力度振幅を，一定振幅 応力に対する応力範囲の打切り限界としている。しかし， 本報告では従来から一般的に用いられているように， $2 \times$ $10^{6}$ 回の応力の繰返しに耐ええる最大応力度振幅を, 疲労 限として用いる。

2）システムトラス接合部の耐力

システムトラス接合部は, 部品が標準化されている。部 品の標準化をするにあたって, 部品の耐力として次のこ とを留意している刘。

(1) 標準ボルト

ISO および JIS 規格のサイズ体系にならう。

(2) 標準エンドコーン

最大対応ボルトの引張強度より 2 割程度上回るように, 引張強度を決める。

(3) 標準ノード

ボルトのねじ抜けが生じないように，めねじの長さはボ ルトの軸径の 1.1 倍（通常の高力ボルトでは 0.8 倍）に する。

3）片振繰返し疲労試験の理由

システムトラスの接合機構として, 次の 3 タイプが考え られる文1。

（1）ノード側ボルトねじ，エンドコーン側透孔

(2) ノード側透孔，エンドコーン側ボルトねじ

(3) ノード側, エンドコーン側ともにボルトねじ

今回の試験体のシステムトラス接合は（1）のタイプで ある。このタイプでは, 引張力を受けた場合のみ, ボル 卜が荷重を負担する。よって, 片振繰返し疲労試験のみ を行った。

4） システムトラスのボルトの長期許容応力度

実際のシステムトラスのボルトとしては，F9Tが用いら れている。その長期許容応力度を, 日本建築学会鋼構造 設計規準文6)により, 以下のように中ポルトとして算定す る。

$\mathrm{F} 9 \mathrm{~T}$ ボルトの引張強さは $90 \mathrm{kgf} / \mathrm{mm}^{2}$ であり, $F$ 值とし ては, $F=0.7 \times 90=63 \mathrm{kgf} / \mathrm{mm}^{2}$ となる。この場合の許 容引張応力度は $0.5 F=31.5 \mathrm{kgf} / \mathrm{mm}^{2}$ である。よって, システムトラスのボルトの長期許容応力度 $\sigma_{a l}$ を 31 
$\mathrm{kgf} / \mathrm{mm}^{2}$ とする。

システムトラスのボルトとして，F10Tを用いる場合で も, ボルトの遅れ破壊等の問題を考慮して, 許容応力度 は, F9Tの場合と同じく, $31 \mathrm{kgf} / \mathrm{mm}^{2}$ としている。

5）ボルトの有効断面積: $A_{s}$

$$
\begin{aligned}
& A_{s}: \pi D_{s}{ }^{2} / 4 \\
& D_{s}=D-0.9382 P \\
& \text { ここで, } \\
& D_{s}: \text { ボルトの有効断面の直径 } \\
& D: \text { ボルトの軸径 } \\
& P: \text { ねじのピッチ. }
\end{aligned}
$$

M45 の場合 : $A_{s}=13.06 \mathrm{~cm}^{2}(P=4.5 \mathrm{~mm}, D=45 \mathrm{~mm})$ $\mathrm{M} 76$ の場合 : $A_{s}=38.89 \mathrm{~cm}^{2}(P=6.0 \mathrm{~mm}, D=76 \mathrm{~mm})$

\section{参考文献}

1）川合広樹, 岩田 衛, 白井貴志：システムトラス構法計 画成立に関する論証，日本建筑学会計画系論文報告集， 第 390 号, pp. 51 59, 1988 年 8 月

2）和田 章, 久保田英之：実規模鋼構造骨組の 3. 次元非線 形解析へのスーパーコンピュータの応用, 日本建築学会 構造系論文報告集，第 394 号, pp. 94 103，1988 年 12 月

3）岩田 衛, 和田 章, 大場高秋, 白井貴志：部品構成さ れた鋼管立体トラスの接合部の回転性能に関する研究， 日本建築学会構造系論文報告集, 第 391 号, pp. 45 58, 1988 年 9 月

4）、西田新一：機械機器破損の原因と対策, 日刊工業新聞社, 1986 年 12 月

5）疲労設計指針改定小委員会：疲労設計指針（案)，日本鋼 構造協会, 1986 年 11 月

6）日本建築学会構造標準委員会：鋼構造設計規準，日本建
築学会, 1970 年 5 月

7）川田雄一：金属の疲労之設計（第 3 版），才ーム社, 1982 年 1 月

8）脇山広三, 平井敬二：高力ボルトの疲労に関する研究, 日本建築学会論文報告集, 第 288 号, pp. $21 \sim 27,1980$ 年 2 月

9）浦島親行，西田新一ほか：各種ボル卜の疲れ特性,八幡 製鉄所技術研究室報告, No. 11，1975 年 10 月

10) ECCS-Technical Comittee 6-Fatigue : Recommendations for the Fatigue Design of Steel Structures, First Edition, 1985

11）日本建築学会：高力ボルト接合設計施工指針（第 2 版), 1983 年 7 月

12）大熊武司：強風による鋼構造物骨組の累積疲労損傷, 配 管技術，日本工業出版，1989 年 5 月

13）:田中道彦, 北郷 薫: 有限要素法によるねじ締結体の解 析, 日本機会学会論文集 ( C 編)， 46 巻 412 号, 1980 年 12 月

14）田中道彦：各種わじ締結体の応力解析, 日本機会学会論 文集 $(\mathrm{C}$ 編)，47巻 417 号，1981 年 5 月

15）田中道彦, 山田 朗：有限要素法によるねじ締結体の解 析（第 3 報，平行刘じ，テーパねじの締結体の応力解析 之考察), 日本機会学会論文集 (C 編)，50 巻 456 号, 1984 年 8 月

16）田中道彦，山田 朗：有限要素法によるねじ締結体の解 析（第 5 報, 外力とボルト軸力の関係についての基礎的 研究), 日本機会学会論文集 ( $\mathrm{C}$ 編), 52 巻 473 号, 1986 年 1 月

（1990 年 10 月 9 日原稿受理，1991 年 2 .月 6 日採用決定） 